Peran Lembaga Swadaya Masyarakat

\title{
FENOMENA PROSTITUSI DI PANTAI SAMAS BANTUL YOGYAKARTA
}

\author{
Vivi Ambarwati
}

\begin{abstract}
s
The phenomenon of prostitution is usually often appear in tourist areas. Prostitution has also appeared in the district of Bantul Samas Beach Yogyakarta despite local laws that prohibit prostitution. This study aims to: 1). Describe the factors that cause the existence of prostitution in Samas Beach, 2). Describe the community and local government efforts in dealing with prostitution in Samas Beach.

This study used descriptive qualitative method of analysis. Informants in this study were CSWs (Commercial Sex Workers) Samas Beach, citizens around and Satpol PP Bantul regency. The research subject was taken by snowball sampling technique. The number of prostitutes in Samas Beach is currently under number 10, so that sampled quite four informants sex workers because of data and information obtained is adequate. The process of data collection is done with the interview, non-participatory observation, field recording and documentation. Researchers itself is a qualitative research instrument, but also coupled with the guidance interview and observation guidelines. Validity of data using data triangulation technique. Techniques in data analysis is the technique of Miles and Huberman interactive analysis with 4 stages, namely: data collection, data reduction, data presentation and conclusion.

The results showed that: 1). The factors causing the existence of prostitution in Samas Beach is divided into two: internal and external factors. Internal factors causing the existence of prostitution in Samas Beach is derived from the self-sex workers Samas Beach is: do not have other life skills, frustration and trauma and sexual needs. While the external factors causing the existence of prostitution in Samas Beach namely: economic factors, call a friend, the narrowness of employment, abuse and misuse of bus terminal facilities stalls $\mathcal{E}$ shacks wild, 2). Grassroots efforts and local governments in dealing with prostitution in Samas Beach is: social control of routine patrolling and monitoring, implementing regulations Bantul district no. 5 year 2007 on the prohibition of prostitution, conducting raids sex workers, providing skills training, lowcost health care through mobile health center and routine supervision of the police station Sanden and police station Bantul.
\end{abstract}

Key words: the phenomenon of prostitution, sex workers and surrounding communities

\section{A. Pendahuluan}

Suatu masyarakat pasti memiliki sistem norma sosial yang mengatur kehidupannya. Norma sebagai pedoman setiap anggota masyarakat untuk berperilaku sebagaimana yang diharapkan oleh seluruh anggota masyarakat. Norma adalah kaidah, aturan pokok, kadar atau patokan yang diterima secara utuh oleh masyarakat guna mengatur kehidupan dan tingkah 
laku sehari-hari, agar hidup ini terasa aman dan menyenangkan. Norma bisa bersifat institusional atau formal dan non institusional atau sosial (norma umum). Norma juga bisa bersifat positif, yaitu sifatnya mengharuskan, menekan atau kompulsif. Norma terdiri dari norma-norma yang ringan lunak, memperbolehkan, sampai penggunaan sedikit paksaan. Sebaliknya norma juga bisa bersifat negatif, yaitu melarang sama sekali bahkan menjadikan tabu atau dilarang melakukannya karena diliputi kekuatan-kekuatan gaib yang lebih tinggi. Norma bisa juga berupa larangan-larangan dengan sanksi keras, hukuman atau tindak pengasingan (Kartini Kartono, 2007, h. 15).

Norma itu muncul sebagai sebuah kesepakatan dan fungsional, ketika norma mengalami disfungsional maka yang terjadi adalah pelanggaran norma. Individu yang dalam berperilaku tidak sesuai dengan norma yang berlaku dianggap sebagai pelanggaran terhadap norma. Seorang individu pada umunya berinteraksi dengan individu atau kelompok lain dalam mencapai tujuan tertentu dengan cara menyesuaikan terhadap normanorma yang berlaku. Sebaliknya, ada individu atau kelompok dalam mencapai tujuannya tidak dapat menyesuaikan norma yang berlaku disebut deviasi. Deviasi atau penyimpangan diartikan sebagai tingkah laku yang menyimpang dari tendensi sentral atau ciri-ciri karakteristik rata-rata dari masyarakat pada umumnya (Kartini
Kartono, 2007, h. 11). Perilakuperilaku yang melanggar dari norma yang ada dalam masyarakat dapat disebut sebagai perilaku menyimpang. Perilaku menyimpang itu sendiri dapat dengan mudah dibedakan dengan tingkah laku normal pada umumnya.

Pelacuran atau prostitusi ialah perbuatan perempuan atau laki-laki yang menyerahkan badannya untuk berbuat cabul secara seksual dengan mendapatkan upah (Kartini Kartono, 2007, h. 216). Prostitusi atau pelacuran selalu ada di semua negara berbudaya, sejak zaman purba sampai sekarang. Timbulnya masalah pelacuran sebagai gejala patologis yaitu sejak adanya penataan relasi seks dan diberlakukannya norma-norma perkawinan (Kartini Kartono, 2007, h. 208).

Prostitusi biasanya kerap muncul di kawasan-kawasan wisata. Demikian pula halnya dengan kawasan wisata Pantai Samas yang juga menjadi daerah praktek prostitusi. Kawasan wisata Pantai Samas adalah sebuah pantai yang terletak di Dusun Ngepet, Desa Srigading, Kecamatan Sanden, Kabupaten Bantul atau sekitar 24 km selatan Kota Yogyakarta. Pantai Samas terkenal dengan ombaknya yang besar, delta-delta sungai dan danau air tawar yang membentuk telaga. Pantai Samas di sebelah barat berbatasan dengan Pantai Pandansari dan Pantai Parangtritis di sebelah timur. Selain ombaknya yang besar, Pantai Samas terkenal dengan angin lautnya yang kencang dan bibir pantai yang curam. 
Namun, di sana muncul praktek prostitusi illegal yang merupakan masalah sosial dalam kehidupan masyarakat. Bupati Kabupaten Bantul Idham Samawi pada tahun 2007 telah mengeluarkan Peraturan Daerah Kabupaten Bantul No. 5 Tahun 2007 tentang Larangan Pelacuran di Wilayah Kabupaten Bantul dan Peraturan Daerah Kabupaten Bantul No. 6 Tahun 2007 tentang Pengendalian, Pengawasan, Larangan Penjualan Minuman Beralkohol di Wilayah Kabupaten Bantul. Satuan Polisi Pamong Praja Kabupaten Bantul sebagai penegak perda tersebut telah melaksanakan berbagai program dan razia namun masih belum optimal sampai saat ini. Setiap razia yang dilaksanakan berhasil menjaring PSK, namun para PSK tersebut beberapa bulan berikutnya akan kembali lagi ke Pantai Samas.

Praktek prostitusi di Pantai Samas telah memperburuk citra kawasan wisata tersebut sehingga pengunjung menjadi enggan berwisata ke sana. Berdasarkan data Dinas Pariwisata Kabupaten Bantul jumlah pengunjung wisata Pantai Samas selalu turun dari tahun ke tahun. Hal itulah yang membuat masyarakat sekitar Pantai Samas terdorong untuk menyusun proposal pada tahun 2010 yang bertujuan meminta bantuan aparat terkait untuk membersihkan Pantai Samas dari prostitusi, judi, mabukmabukan dan sebagainya. Masyarakat sekitar bekerjasama dengan aparat setempat melakukan razia dan pengawasan. Berkat kerjasama masyarakat dan aparat setempat itulah prostitusi di Pantai Samas dapat ditekan. Kenyataannya, hingga kini praktek prostitusi terselubung tersebut masih ada.

\section{B. Kajian Teori}

1. Fenomena

Kata fenomena berasal dari Bahasa Yunani; phainomenon artinya apa yang terlihat, dalam Bahasa Indonesia bisa berarti:

a. gejala, misalkan gejala alam,

b. hal-hal yang dirasakan dengan pancaindra,

c. hal-hal mistik atau klenik,

d. fakta, kenyataan, kejadian (Wikipedia, 2010).

Fenomena juga dapat diartikan sebagai hal-hal atau fakta yang dapat disaksikan dengan pancaindera dan dapat diterangkan serta dapat dinilai secara ilmiah (Kamus Besar Bahasa Indonesia, 2002, h. 315). Prostitusi di Pantai Samas merupakan salah satu fenomena atau kenyataan tentang apa yang terjadi di masyarakat dan dapat disaksikan dengan pancaindera dan dapat dinilai secara ilmiah.

2. Penyimpangan atau Deviasi

Tingkah laku menyimpang adalah tingkah laku yang tidak bisa diterima oleh masyarakat pada umumnya dan tidak sesuai dengan norma sosial yang ada (Kartini Kartono, 2007, h. 14). Deviasi atau penyimpangan diartikan sebagai tingkah laku yang menyimpang dari tendensi sentral atau ciri-ciri 
karakteristik rata-rata masyarakat pada umumnya. Deviasi adalah penyimpangan terhadap kaidah dan nilai-nilai masyarakat (Soerjono Soekanto, 2007, h. 189).

3. Prostitusi

Kata prostitusi berasal dari Bahasa Latin pro-stituere atau prostauree, yang berarti membiarkan diri berbuat zina, melakukan persundalan, percabulan dan perendakan. Sedang kata prostitue adalah pelacur atau sundal. Dikenal pula dengan istilah WTS atau wanita tuna susila dan PSK atau pekerja seks komersial (Kartini Kartono, 2007, h. 207).

Prostitusi dalam perspektif gender diartikan sebagai suatu bentuk kekerasan terhadap perempuan yang diselenggarakan oleh suatu mekanisme ekonomi yang merugikan kaum perempuan (Farida Hanum, 2007, h. 11). Prostitusi adalah bentuk penyimpangan seksual, dengan pola-pola organisasi dorongan seks yang tidak wajar dan tidak terintegrasi dalam bentuk pelampiasan nafsu-nafsu seks tanpa terkendali dengan banyak orang (promiskuitas), disertai eksploitasi dan komersialisasi seks yang impersonal tanpa afeksi sifatnya. Prostitusi juga dapat dikatakan sebagai perbuatan perempuan atau laki-laki yang menyerahkan badannya untuk berbuat cabul secara seksual dengan mendapatkan upah (Kartini Kartono, 2007, h. 216). Kesimpulannya prostitusi dapat diartikan sebagai suatu pekerjaan menyerahkan diri kepada umum untuk melakukan perbuatan- perbuatan seksual dengan mendapat upah.

4. Teori

a. Teori Fenomenologi

Konsep fenomenologi

bermula dari pandangan Edmund Husserl yang meyakini bahwa sesungguhnya objek ilmu itu tidak terbatas pada hal-hal yang empirik, tetapi juga mencakup fenomena yang berada di luar itu seperti persepsi, pemikiran, kemauan dan keyakinan subyek tentang "sesuatu" di luar dirinya (Muhammad Idrus, 2007, h. 79).

Filsafat fenomenologi yang terfokus pada kesadaran, memiliki sejarah panjang, namun berupaya mengembangkan varian sosiologis fenomenologi. Para fenomenolog percaya bahwa pada makhluk hidup tersedia berbagai cara untuk menginterpretasikan pengalaman melalui interaksi dengan orang lain (Lexy J. Moleong, 2006, h. 9). Prostitusi oleh banyak orang mungkin dianggap sebagai perilaku menyimpang, namun berbeda dengan PSK itu sendiri yang menganggap prostitusi sebagai pekerjaan dan profesi untuk memenuhi kebutuhan hidup seperti orang lain.

Menurut Husserl, secara harfiah fenomenologi adalah suatu filsafat yang menggali akar-akar pengetahuan dan pengalaman kita. Sebutan fenomenologis berarti studi tentang cara dimana fenomena atau hal-hal yang kita sadari muncul kepada kita dan cara yang paling mendasar dari pemunculannya adalah sebagai suatu aliran pengalaman-pengalaman inderawi yang berkesinambungan yang kita 
terima melalui panca indera kita. Fenomenologi juga tertarik dengan pengidentifikasian masalah ini dari dunia pengalaman inderawi yang bermakna kepada dunia yang penuh dengan objek-objek yang bermakna, suatu hal yang semula terjadi di dalam kesadaran individual kita secara terpisah dan kemudian secara kolektif di dalam interaksi antara kesadarankesadaran (Ian Craib, 1992, h. 126129). Persoalan pokok yang diterangkan oleh teori ini justru menyangkut persoalan pokok ilmu sosial sendiri, yakni bagaimana kehidupan bermasyarakat itu dapat terbentuk (Geroge Ritzer, 2002, h. 59). Penelitian tentang prostitusi di Pantai Samas merupakan fenomena dan kejadian nyata yang dapat ditangkap dengan panca indera kita dan dapat dikaji secara ilmiah melalui teori fenomenologi.

b. Teori Anomi

Robert

K. Merton

menyatakan bahwa anomi terjadi ketika terdapat disjungsi akut antara norma-norma dan tujuan kultural yang terstruktur secara sosial dengan kemampuan anggota kelompok untuk bertindak menurut norma dan tujuan tersebut. Jadi, karena posisi mereka dalam struktur sosial masyarakat, beberapa orang tidak mampu bertindak menurut nilai-nilai normatif. Kebudayaan menghendaki adanya beberapa jenis perilaku yang dicegah oleh struktur sosial (Geroge Ritzer, 2002, h. 273).

Misalnya, dalam suatu masyarakat terdapat kebudayaan yang menekankan pada kesuksesan ekonomi, masyarakat yang tidak memiliki modal cukup dan pendidikan rendah memiliki kesempatan yang kecil atau bahkan tidak ada sama sekali untuk memperoleh kesuksesan ekonomi. Situasi semacam itu menimbulkan adanya anomi dan akibatnya terdapat kecenderungan ke arah perilaku menyimpang. Seseorang yang menjadi PSK untuk memperoleh kesuksesan ekonomi adalah contoh dari penyimpangan yang ditimbulkan oleh disjungsi antara nilai kultural dengan caracara sosial kultural dalam mencapai nilai-nilai tersebut (Geroge Ritzer, 2002, h. 273). Demikian pula dengan keberadaan PSK di Pantai Samas yang ingin mencapai kesuksesan ekonomi dengan cara menjual diri. Mereka memiliki taraf ekonomi rendah sehingga mendorong mereka terjun di dunia prostitusi untuk kesejahteraan hidupnya seperti masyarakat lain pada umumnya.

c. Teori Labelling

Teori labeling atau teori pemberian cap atau dapat disebut pula teori reaksi masyarakat. Teori ini menekankan pada pentingnya definisi-definisi sosial dan sanksisanksi sosial negatif yang dihubungkan dengan tekanantekanan individu untuk masuk dalam tindakan yang lebih menyimpang. Analisis tentang pemberian cap itu dipusatkan pada reaksi orang lain. Artinya, ada orang-orang yang memberi definisi, julukan atau pemberi label 
(definers/labelers) pada individuindividu atau tindakan yang menurut penilaian orang tersebut adalah negatif (J. Dwi Narwoko dan Bagong Suyatno, 2010, h. 114).

Demikian halnya dengan para wanita yang berjualan minuman dan makanan di sepanjang pantai Samas, setelah mereka mendapatkan cap sebagai PSK maka mereka justru akan menjadi PSK yang sebenarnya. Artinya, dengan adanya cap yang dilekatkan pada diri seseorang maka orang yang telah diberi cap cenderung mengembangkan konsep diri yang menyimpang dan kemungkinan berakibat pada suatu karier yang menyimpang (J. Dwi Narwoko dan Bagong Suyatno, 2010, h. 115).

d. Teori Kontrol

Latar belakang munculnya teori ini adalah penyimpangan merupakan hasil dari kekosongan kontrol sosial atau pengendalian sosial. Teori ini dibangun atas dasar pandangan bahwa setiap manusia cenderung untuk tidak patuh pada hukum dan memiliki dorongan untuk melakukan pelanggaran hukum (J. Dwi Narwoko dan Bagong Suyatno, 2010, h. 116).

Kontrol sosial dibutuhkan dalam upaya mengatasi adanya prostitusi illegal di Pantai Samas. Bentuk konkret kontrol sosialnya adalah Peraturan Daerah Kabupaten Bantul No. 5 Tahun 2007 tentang larangan prostitusi. Selain itu, kerjasama masyarakat sekitar dengan aparat setempat untuk mengatasi praktek prostitusi di Pantai Samas juga sesuai jika dianalisis dengan teori kontrol.

\section{Metode Penelitian}

Penelitian mengenai fenomena prostitusi di Pantai Samas Bantul Yogyakarta memerlukan pendekatan penelitian yang mampu menelaah fenomena berupa kejadian, persepsi, motivasi, tindakan dan lain sebagainya untuk kemudian dideskripsikan dalam data berupa kalimat atau kata-kata. Berdasarkan hal tersebut, maka penelitian ini menggunakan pendekatan secara kualitatif deskriptif. Metode kualitatif mengutamakan bahan yang sukar dapat diukur dengan angka-angka atau dengan ukuran-ukuran lain yang bersifat eksak, walaupun bahan-bahan tersebut terdapat dengan nyata di dalam masyarakat (Soerjono Soekanto, 2007, h. 42). Data-data tertulis dalam penelitian ini diperoleh dari pekerja seks komersial (PSK) dan anggota masyarakat di sekitar Pantai Samas.

Penelitian kualitatif juga merupakan sebuah penelitian yang bermaksud untuk memahami fenomena tentang apa yang dialami oleh subyek penelitian misalnya; perilaku, persepsi, motivasi, tindakan dan lain-lain secara holistik dan dengan cara dideskripsikan dalam bentuk katakata dan bahasa, pada suatu konteks khusus yang alamiah dengan memanfaatkan berbagai metode ilmiah (Lexy J. Moleong, 2006, h. 6). Berbagai macam kejadian yang dialami oeh PSK yang merupakan sumber data yang dapat dijadikan bahan penelitian. Berbagai macam kejadian tersebut selanjutnya ditelaah atau dipahan ${ }_{14}$ peneliti sebagai satu alur kejadia 
yang mampu mendefinisikan terhadap data yang dikaji.

Pendekatan secara deskriptif (deskriptif research) dalam hal ini merupakan sebuah pendekatan dengan mengeksplorasi dan klarifikasi mengenai sebuah fenomena atau kenyataan sosial, dengan jalan mendeskripsikan sejumlah variabel yang berkenaan dengan masalah atau unit yang diteliti. Jenis penelitian ini tidak sampai mempersoalkan jalinan hubungan antar variabel yang ada, tidak untuk menarik generasi yang menjelaskan variabel yang menyebabkan suatu gejala atau kenyataan sosial. Maka dari itu, dalam penelitian deskriptif tidak menggunakan pengujian hipotesis (Sanapiah Faisal, 2005, h. 20).

Penelitian mengenai fenomena prostitusi di Pantai Samas ini secara kualitatif deskriptif akan mendekatkan pada hasil kajian berupa berbagai macam fenomena yang terjadi di masyarakat. Kejadian tersebut selanjutnya secara deskriptif dapat didefinisikan sebagai sebuah eksplorasi atas fenomena atau kenyataan sosial tertentu yang ada di masyarakat sekitar kita.

Subyek penelitian ini adalah PSK di Pantai Samas yang diambil dengan menggunakan tenik penentuan sampel snowball sampling. Snowball sampling atau sampel bola salju merupakan teknik penentuan sampel yang awalnya adalah berjumlah kecil, kemudian sampel berikutnya ini menjadi berkembang dan semakin banyak dan seterusnya ibarat bola salju yang menggelinding ke bawah semakin besar bentuknya (Rosady Ruslan, 2004, h. 157). Jadi, Snowball sampling adalah suatu teknik yang menentukan satu atau beberapa responden. Melalui responden tersebut ditelusuri responden lainnya. Kita menanyakan kepada responden tersebut siapa-siapa saja temannya yang bisa dihubungi untuk diwawancarai.

Snowball sampling adalah teknik pengambilan sampel dari populasi yang tidak jelas keberadaaan anggotanya dan tidak pasti jumlahnya dengan cara menemukan satu sampel, untuk kemudian dari sampel tersebut digali keterangan mengenai keberadaan sampel-sampel lain, terus demikian secara berantai. Misalnya, kita telah mewawancarai responden yaitu salah satu PSK, maka kita menanyakan siapa lagi teman sesama PSK lainnya untuk diwawancarai berikutnya. Selanjutnya, dari temannya tadi dicari lagi informasi teman-teman lainnya. Begitu seterusnya, sampai sampel dirasa cukup untuk memperoleh data yang diperlukan, sampai mentok atau sudah tidak terkorek lagi keterangan sampel lainnya, sampai data yang diperoleh dipandang sudah cukup memadai untuk menjawab permasalahan penelitian.

Penelitian ini menggunakan beberapa teknik pengumpulan data yakni; observasi (pengamatan), interview (wawancara) dan dokumentasi. 
1. Observasi (pengamatan)

Observasi atau pengamatan merupakan setiap kegiatan pengukuran yang dilakukan di lapangan. Observasi dilakukan dengan menggunakan indera penglihatan yang berarti tidak mengajukan pertanyaanpertanyaan.

Secara operasional, dalam penelitian ini proses observasi berhubungan dengan proses penentuan sampel yang akan dijadikan responden dalam penelitian. Penelitian ini memerlukan observasi karena perlu diamati mengenai lokasi Pantai Samas dan keberadaan PSK di sana.

2. Interview (wawancara)

Interview atau wawancara merupakan pengumpulan data dengan mengajukan pertanyaan secara langsung oleh pewawancara (pengumpul data) kepada responden dan jawaban responden dicatat atau direkam dengan alat perekam.

Metode wawancara dalam penelitian ini dilakukan secara mendalam untuk menggali berbagai macam informasi dari narasumber yakni PSK, aparat setempat, anggota masyarakat dan pengunjung di Pantai Samas tersebut.

\section{Dokumentasi}

Dokumentasi merupakan teknik pengumpulan data yang tidak langsung ditujukan oleh subyek penelitian. Dokumentasi di sini lebih pada mengumpulkan dokumentasi pendukung data-data penelitian yang dibutuhkan (Irawan Soehartono, 2004, 67-69). Metode dokumentasi diperlukan dalam penelitian ini untuk mengumpulkan berbagai macam data pendukung seperti foto, dokumentasi, liputan di media dan sebagainya.

Pemeriksaan keabsahan data menggunakan teknik triangulasi yang merupakan sebuah teknik pemeriksaan keabsahan data dengan memanfaatkan sesuatu di luar data untuk keperluan pengecekan atau pembanding terhadap data itu (Husaini Usman, 1995, h. 47). Triangulasi yang digunakan adalah triangulasi metode dan sumber.

Metode yang digunakan untuk memperoleh data dalam penelitian digunakan metode pengamatan, wawancara dan analisa dokumen yang diperoleh. Selanjutnya, dilakukan teknik triangulasi sumber yang dilakukan dengan meminta penjelasan lebih lanjut. Data-data yang diperoleh dengan menggunakan informan langsung serta dengan informan lain yang mendukung. Triangulasi kemudian digunakan untuk mengecek informasi yang diberikan oleh informan pada saat yang berbeda.

Analisis data merupakan proses penyederhanaan data yang diperoleh dalam penelitian ke dalam bentuk yang lebih mudah ditelaah dan diimplementasikan. Teknik analisis data yang digunakan dalam penelitian ini adalah analisis interaktif dari Miles dan Huberman. Teknik ini menggunakan empat komponen analisis yaitu pengumpulan data, reduksi data, penyajian data dan penarikan kesimpulan (verifikasi) yang dilakukan secara terus 
menerus sehingga membentuk sebuah siklus. Data yang diperoleh dalam penelitian tentang fenomena prostitusi di Pantai Samas selanjutnya dianalisis dengan analisis interaktif Miles dan Huberman.

\section{Pembahasan}

Penelitian ini dianalisis dengan teori fenomenologi karena merupakan sebuah fenomena sosial yang nyata dalam kehidupan masyarakat. Penelitian ini menginterpretasikan pengalaman PSK secara mendalam sesuai kenyataan tanpa pendapat peneliti sendiri. Sehingga, segala sesuatunya dipaparkan apa adanya sesuai kesadaran PSK itu sendiri. Hasil analisis penelitian tentang fenomena prostitusi di Pantai Samas Bantul Yogyakarta adalah sebagai berikut:

1. Faktor-faktor

Penyebab

Prostitusi di Pantai Samas

Fenomena prostitusi di Pantai Samas muncul karena berbagai faktor. Berbagai faktor tersebut dibedakan menjadi 2 yaitu faktor internal dan faktor eksternal. Faktor internal adalah faktor dari dalam PSK itu sendiri yang melatarbelakangi mereka menjadi PSK di Pantai Samas. Faktor eksternal adalah faktor dari luar yang berasal dari lingkungan dan kondisi sekitar sehingga mendukung adanya prostitusi di Pantai Samas tersebut.

a. Faktor intern atau dari dalam diri PSK sehingga menimbulkan adanya prostitusi di Pantai Samas antara lain:

1) Tidak memiliki keterampilan hidup yang lain Para PSK di Pantai Samas selain berpendidikan rendah juga tidak memiliki keterampilan hidup yang lain. Keterampilan lain yang mereka miliki hanya sebatas menjadi pembantu rumah tangga. Bekerja sebagai pembantu rumah tangga memang tidak membutuhkan keahlian khusus, namun mereka lebih memilih menjadi PSK saja. Alasannya, jelas karena lebih mudah dan tidak terlalu membutuhkan banyak tenaga. Penghasilan sebagai PSK juga jauh lebih banyak jika dibandingkan dengan bekerja sebagai pembantu rumah tangga. Terkadang mereka mencari penghasilan tambahan dengan menjual walang goreng yang mereka tangkap sendiri lalu dititipkan di warung-warung.

Para PSK tersebut malas jika diajari keterampilan lain seperti menjahit ataupun kerja di salon karena butuh waktu dalam proses mempelajari keterampilan tersebut. Para PSK di Pantai Samas lebih memilih memanfaatkan waktu untuk mencari pelanggan dan langsung dibayar daripada harus mempelajari keterampilan lain. Selain itu, letak Pantai Samas diujung desa sehingga jika membuka usaha salon atau jahit baju kurang strategis. Hal ini juga semakin membuat mereka tidak mau ikut kursus keterampilan lain untuk beralih profesi. 
2) Frustasi dan trauma

Frustasi dan trauma akibat masa lalu juga dapat memicu seseorang terjun ke dunia prostitusi. Fenomena prostitusi di Pantai Samas juga dapat terjadi karena frustasi dan trauma yang dialami seseorang di masa lalu sebelum ia menjadi PSK. Beberapa PSK ada yang sakit hati karena dianggap mandul maupun dilarang pergi oleh orangtua sehingga membuatnya stres. Kesimpulannya, frustasi dan trauma masa lalu yang dialami PSK membuat mereka terjun ke dunia prostitusi di Pantai Samas.

3) Kebutuhan seksual

Para PSK di Pantai Samas mayoritas adalah janda yang ditinggal suaminya. ada yang dicerai secara resmi dan ada pula yang ditinggal begitu saja sampai saat ini. Kebutuhan seksual mereka setelah ditinggal suami tentu saja tidak terpenuhi maka, mereka mencari pelanggan sebagai pengganti peran suami untuk memenuhi kebutuhan seksualnya. Hal tersebut mendorong mereka terjun ke dunia prsotitusi. Kebutuhan biologis berupa dorongan seks mereka bisa tersalurkan dengan melakukan hubungan suami-istri dengan pelanggan di Pantai Samas.

Kesimpulannya, berdasarkan wawawancara dengan beberapa PSK, faktor penyebab dari diri mereka sendiri atau faktor intern penyebab mereka terjun ke dunia prostitusi di Pantai Samas adalah tidak memiliki keterampilan hidup yang lain, frustasi serta trauma dan kebutuhan seksual. b. Faktor ekstern yang menyebabkan adanya prostitusi di Pantai Samas antara lain:

1) Faktor ekonomi

Salah satu faktor penyebab utama munculnya fenomena prostitusi di Pantai Samas adalah faktor ekonomi PSK. Para PSK Pantai Samas pada umumnya adalah janda yang resmi dicerai suami maupun tidak. Ada PSK yang benar-benar telah resmi dicerai oleh suaminya, namun ada juga yang ditinggal begitu saja oleh suaminya. Selanjutnya janda-janda tersebut menjadi PSK untuk memenuhi kebutuhan ekonomi hidupnya. Hal ini sesuai dengan teori anomi bahwa para janda tersebut menjadi PSK karena ingin memperoleh kesuksesan ekonomi akibat tekanan budaya masyarakat. Anomi terjadi ketika terdapat disjungsi akut antara norma-norma dan tujuan kultural yang terstruktur secara sosial dengan kemampuan anggota kelompok untuk bertindak menurut norma dan tujuan tersebut. Jadi, karena posisi mereka dalam struktur sosial masyarakat, beberapa orang tidak mampu bertindak menurut nilai-nilai normatif. Kebudayaan menghendaki adanya beberapa jenis perilaku yang dicegah oleh struktur sosial. Pada umumnya faktor ekonomi memang merupakan penyebab utama para wanita yang datang dari berbagai daerah tersebut untuk menjadi PSK. Para PSK di Pantai Samas awal mulanya datang ke Samas dengan berbagai alasan namun ujung-ujungnya 
mereka itu menjadi PSK karena terdesak oleh kebutuhan ekonomi.

2) Ajakan teman

Seseorang juga bisa menjadi PSK karena pengaruh dari teman dan lingkungannya. Buktinya, para PSK di Pantai Samas juga mengalaminya. Bahkan seseorang yang tidak tahu dan tidak ada niat sama sekali bisa terjebak dalam dunia prostitusi hanya karena ajakan dari teman. Ajakan teman memang merupakan salah satu faktor penyebab para wanita tersebut menjadi PSK di dunia prostitusi Pantai Samas. Beberapa PSK juga mengakui bahwa dirinya terjun ke dunia prostitusi di Pantai Samas karena pengaruh teman dekatnya.

3) Sempitnya lapangan pekerjaan

Sempitnya lapangan kerja serta diperparah dengan kondisi para PSK di Pantai Samas yang ratarata memiliki pendidikan yang rendah semakin membuat mereka terjepit dan memilih bekerja di dunia prostitusi. Hal ini semakin mempersempit peluang mereka untuk mendapatkan pekerjaan lain. Pendidikan tertinggi PSK Samas adalah tamat SMP. Bahkan adapula PSK yang cukup hanya bisa baca tulis sehingga tidak tamat sekolah dasar. Pendidikan rendah semakin mempersempit kesempatan mereka untuk mendapatkan pekerjaan yang lebih layak. Sempitnya lapangan kerja saat ini membuat mereka tidak mempunyai peluang untuk pekerjaan yang lain. Akhirnya, menjadi PSK merupakan jalan pintas untuk tetap hidup di dunia ini.

4) Penyalahgunaan fasilitas terminal bus

Terminal sebagai tempat umum biasanya ramai oleh para penumpang dari berbagai daerah dan tujuan masing-masing. Terminal bus di Samas ini menjadi faktor pendukung adanya prostitusi di sana karena sesuai dengan hasil wawancara PSK yang menyatakan bahwa terminal dijadikan tempat mencari pelanggan. Kesimpulannya, berdasarkan wawancara dengan pengunjung dan PSK di Pantai Samas dapat diketahui bahwa adanya fasilitas terminal bus dan lokasi yang strategis telah disalahgunakan oleh pihak-pihak tertentu hingga menjadi faktor penyebab adanya praktek prostitusi di sana.

5) Penyalahgunaan warung dan gubuk-gubuk liar Masyarakat yang tinggal di sekitar Pantai Samas terdiri dari dua RT serta 100 kepala keluarga. Gubuk-gubuk liar tersebut merupakan warung yang menjual makanan ringan, minuman ringan dan es kelapa muda. Namun, di gubuk liar tersebut juga dijadikan tempat untuk menjual minumminuman keras dan praktek prostitusi. Gubuk-gubuk tersebut biasanya didirikan di sepanjang pantai.

2. Upaya Masyarakat dan Pemerintah Daerah Menanggulangi Prostitusi di Pantai Samas 
Fenomena prostitusi yang terjadi di Pantai Samas menimbulkan berbagai dampak negatif yang meresahkan warga sekitar Pantai Samas. Para PSK di Pantai Samas merupakan para pendatang yang tinggal di sekitar Pantai Samas. Masyarakat sekitar memberikan cap negatif pada mereka karena mereka datang hanya untuk menjadi PSK. Dandanan wanita-wanita tersebut juga mencerminkan diri sebagai PSK. Hal ini sesuai dengan teori labeling atau teori pemberian cap atau dapat disebut pula teori reaksi masyarakat. Analisis tentang pemberian cap itu dipusatkan pada reaksi orang lain.

Puncaknya pada tahun 2010 masyarakat sekitar Pantai Samas pro aktif bekerja sama dengan aparat setempat melaksanakan razia besar-besaran hingga dapat menekan jumlah PSK di kawasan wisata tersebut. Berbagai upaya penanggulangan prostitusi juga dilakukan karena ingin meramaikan kembali wisata Pantai Samas yang sepi pengunjung karena keberadaan PSK tersebut. Mengingat berbagai dampak tersebut maka muncul adanya upaya dari masyarakat dan pemerintah untuk menanggulangi prostitusi di Pantai Samas Bantul Yogyakarta, antara lain sebagai berikut:

a. Kontrol sosial berupa ronda dan pengawasan rutin

Sebagian besar warga sekitar Pantai Samas tidak menghendaki adanya praktek prostitusi di sana karena khawatir generasi mudanya akan terpengaruh dampak negatif dari prostitusi tersebut. Selain itu, prostitusi di Pantai Samas memperburuk citra wisata Pantai Samas hingga jumlah pengunjungnya selalu menurun di tiap tahunnya. Prostitusi memang suatu hal yang sulit untuk dihilangkan. Namun, kontrol sosial dari masyarakat Kring IV Gunung Wingko Srigading, Sanden, Bantul Yogyakarta dapat membuktikan bahwa saat ini prostitusi di Samas telah diminimalisir. Walaupun sebenarnya saat ini di sana masih ada beberapa PSK yang bertahan karena motif ekonomi.

b. Melaksanakan peraturan daerah Kabupaten Bantul No.5 Tahun 2007 tentang larangan prostitusi

Sejak tahun 2007 pemerintah daerah Kabupaten Bantul telah melarang prostitusi di wilayah Bantul dengan mengeluarkan Perda No. 5 Tahun 2007. Pasal 3 dalam perda tersebut melarang adanya praktek pelacuran atau prostitusi dan mucikari. Ketentuan pidananya yaitu kurungan penjara 3 bulan dan denda 10 juta rupiah. Peraturan daerah ini dibuat oleh Bupati Idham Samawi pada bulan Mei. Penegakan perda ini sepenuhnya diserahkan pada Satuan Polisi Pamong Praja Kabupaten Bantul. Satpol PP sebagai penegak Perda Kabupaten Bantul No. 5 Tahun 2007 sampai saat ini masih terus bekerja sama dengan masyarakat sekitar Pantai Samas untuk mengatasi prostitusi tersebut.

c. Mengadakan razia PSK

Salah satu cara untuk mengatasi prostitusi adalah dengan mengadakan razia PSK. Selama ini razia yang paling optimal yaitu 
pada tahun 2010 karena terdapat kerjasama antara Satpol PP, Polres, Polsek dan warga sekitar. Kesimpulannya, razia yang sering diadakan oleh pemerintah daerah tidak akan berhasil tanpa dukungan penuh warga setempat. Tindak lanjut dari razia tersebut yaitu PSK yang tertangkap razia selanjutnya dibawa ke Polres untuk diadili dan ditampung di Dinas Sosial. Setelah proses pengadilan maka PSK-PSK tersebut akan dipulangkan ke daerahnya masing-masing.

d. Memberikan pelatihan keterampilan

Sejak dahulu sudah ada pelatihan keterampilan yang diupayakan bagi PSK Pantai Samas, namun terdapat banyak kendala sehingga kurang optimal. Jadi, pelatihan keterampilan bagi PSK di Samas sekarang jarang dilakukan sehingga mereka tetap menjalankan profesinya dan tidak ingin beralih profesi.

e. Pelayanan kesehatan murah melalui puskesmas keliling Kesehatan PSK sangat rentan terhadap penyakit-penyakit kelamin karena hubungan seksual yang dilakukan dengan banyak orang. Puskesmas keliling setiap satu minggu sekali datang ke sana untuk menawarkan obat-obatan dengan harga murah yang menjadi solusi bagi kesehatan mereka. Para PSK sebenarnya takut terkena AIDS dan semacamnya namun tidak berani memeriksakan diri ke dokter umum karena malu. Kesimpulannya, kesehatan para PSK di Pantai Samas kurang terkontrol dan jarang diberikan penyuluhan kesehatan yang optimal. Para PSK cenderung tidak terlalu peduli dengan kesehatan masing-masing dan mengutamakan penghasilan.

f. Pengawasan rutin dari Polsek Sanden dan Polres Bantul

Pengawasan rutin selain dari masyarakat sekitar Pantai Samas juga dilakukan oleh pihak Polsek dan Polres. Setiap diadakan razia, Polsek dan Polres bersifat mengamankan agar tidak terjadi kerusuhan. Keamanan menjadi tanggungg jawab Polsek dan Polres setempat.

\section{E. Simpulan}

Hasil penelitian tentang fenomena prostitusi di Pantai Samas Bantul Yogyakarta ini menunjukkan bahwa:

1. Faktor-faktor penyebab adanya prostitusi di Pantai Samas dibedakan menjadi dua yaitu faktor intern dan ekstern.

a. Faktor intern penyebab adanya prostitusi di Pantai Samas meliputi:

1) Tidak memiliki keterampilan hidup lain

2) Frustasi dan trauma

3) Kebutuhan seksual

b. Faktor ekstern penyebab adanya prostitusi di Pantai Samas meliputi:

1) Faktor ekonomi

2) Ajakan teman

3) Sempitnya lapangan pekerjaan

4) Penyalahgunaan fasilitas terminal bus 
5) Penyalahgunaan warung dan gubuk-gubuk liar

2. Upaya masyarakat dan pemerintah daerah dalam mengatasi prostitusi di Pantai Samas adalah sebagai berikut:

a. Kontrol sosial berupa ronda dan pengawasan rutin

b. Melaksanakan peraturan daerah Kabupaten Bantul no. 5 tahun 2007 tentang larangan prostitusi

c. Mengadakan razia PSK

d. Memberikan pelatihan keterampilan

e. Pelayanan kesehatan murah melalui puskesmas keliling

f. Pengawasan rutin dari Polsek Sanden dan Polres Bantul

\section{Daftar Pustaka}

Asmadi Alsa. 2003. Pendekatan Kualitatif serta Kombinasinya dalam Penelitian Psikologi. Yogyakarta: Pustaka Pelajar Offset.

Dwi Narwoko dan Bagong Suyatno, J. 2010. Sosiologi Teks Pengantar dan Terapan Edisi ke Tiga. Jakarta: Kencana Prenada Media Group.

Husaini Usman, dkk. 1995. Metodologi Penelitian Sosial. Jakarta: Bumi Aksara.

Ian Craib. 1992. Teori-teori Sosial Modern. Jakarta: Rajawali.

Irawan Soehartono. 2004. Metode Penelitian Sosial. Bandung: Remaja Rosdakarya.

Imam Asyari. 1986. Patologi Sosial. Surabaya: Usaha Nasional.
Kartini Kartono. 2007. Patologi Sosial Jilid I. Jakarta: Raja Grafindo Persada

Khairudin. 2002. Sosiologi Keluarga. Yogyakarta: Liberty Yogyakarta.

Koentjaraningrat. 1972. Antropologi Sosial. Jakarta: Dian Rakyat.

Lexy J. Moleong. 2006. Metodologi Penelitian Kualitatif. Bandung: Remaja Rosdakarya.

Mamik Nuriyah S dan N oha. 2005. Khitan Wanita dan rrostıtusi. Yogyakarta: Insania Press.

Miles dan Huberman. 1992. Analisa Data Kualitatif. Jakarta: UI Press.

Muhammad Idrus. 2007. Metode Penelitian Ilmu-ilmu Sosial (Pendekatan Kualitatif dan Kuantitatif). Yogyakarta: UII Press.

Rianto Adi. 2005. Metodologi Penelitian Sosial dan Hukum. Jakarta: Granit.

Ritzer, George. 2002. Sosiologi Ilmu Pengetahuan Berparadigma Ganda. Jakarta: Raja Grafindo Persada.

------ and Douglas J. Goodman. 2009. Teori Sosiologi. Yogyakarta: Kreasi Wacana.

Rosady Ruslan. 2004. Metode Penelitian Public Relations dan Komunikasi. Jakarta: Raja Grafindo Persada. 
| Peran Lembaga Swadaya Masyarakat

Sanapiah Faisal. 2005. Format-format Penelitian Sosial. Jakarta: Raja Grafindo Persada.

Soerjono Soekanto. 2007. Sosiologi Suatu Pengantar. Jakarta: Raja Grafindo Persada.
Soleman B Taneko. 1984. Struktur dan Proses Sosial, Suatu Pengantar Sosiologi Pembangunan. Jakarta: Rajawali.

Suharismi Arikunto. 1993. Prosedur Penelitian Suatu Pendekatan Praktis. Jakarta: Rieneka Cipta. 